\title{
An investigation of qualitative variations of groundwater resources under municipal wastewater recharge using numerical and laboratory models, Nazarabad plain, Iran
}

\author{
Nezhla Amiri ${ }^{1} \cdot$ Mohammad Nakhaei $^{1}$ \\ Received: 9 July 2020 / Accepted: 20 January 2021 / Published online: 18 June 2021 \\ (C) The Author(s) 2021
}

\begin{abstract}
Municipal wastewater irrigation induces elevated concentrations of heavy metals in the soil which their further leaching leads to groundwater contamination in the long run. In this study, both column experiment and 5-year prediction modeling using HYDRUS-1D were conducted to investigate the probable adsorption and transport of 10 different metals including As, Ba, $\mathrm{Cr}, \mathrm{Cu}, \mathrm{Mo}, \mathrm{Ni}, \mathrm{Pb}, \mathrm{Rb}, \mathrm{Sr}$, and $\mathrm{Zn}$ in an alkaline soil from Nazarabad plain in Iran which has been irrigated with treated urban wastewater for several years. The obtained results revealed that reaching the equilibrium rate for the mentioned elements during 1825 days ( $=5$ years) was as follows: $\mathrm{Mo}>\mathrm{Cr}>\mathrm{Rb}>\mathrm{Zn}>\mathrm{Ni}>\mathrm{Ba}>\mathrm{Sr}>\mathrm{Pb}>\mathrm{As}>\mathrm{Cu}$. The finding implies that molybdenum (Mo) and copper $(\mathrm{Cu})$ are the most mobile and the most adsorbent heavy metals in the soil, respectively. Higher mobility poses the greater potential risk of leaching into groundwater resources. Overall, experimental and numerical modelings had good accordance and were capable of describing the actual condition.
\end{abstract}

Keywords Treated municipal wastewater · Soil column experiment $\cdot$ Contaminant transport modeling $\cdot$ HYDRUS-1D $\cdot$ Trace element $\cdot$ Heavy metal $\cdot$ Nazarabad plain

\section{Introduction}

Municipal wastewater is an effluent that is produced mainly by domestic and non-industrial commercial activities (Maliva and Missimer 2012). While suspended and soluble organic and inorganic solids have a little share, $99.94 \%$ of its total volume consists of pure water (Abel 2014; Drinan and Spellman 2013; Pescod 1992). Compared to other types of effluents, municipal wastewater reuse is more possible due to its characteristics (Charkhestani et al. 2015). Reconsumption of wastewater has an old history all over the world, and the indications of its reuse date back to at least 5000 years ago and more precisely to the Minoan civilization

Responsible Editor: Xianliang Yi

Mohammad Nakhaei

nakhaei@khu.ac.ir

Nezhla Amiri

nezhla.amiri@gmail.com

1 Department of Applied Geology, Faculty of Earth Sciences, Kharazmi University, Mofateh Ave, Tehran, Iran of ancient Greece (Maliva and Missimer 2012). Nowadays, the major use of wastewater is in irrigation, which is the direct/ indirect non-potable reuse of wastewater (Fatta-Kassinos and Kummerer 2016; Keremane 2017). Providing requisite water in arid regions, supplying required plant nutrients and thus reducing the expenses concerning agronomic fertilizers, and ultimately being a secondary water resource increasing in amount along with population growth are some benefits of wastewater reuse (Jafari et al. 2018; Maliva and Missimer 2012).

From another aspect, reutilizing wastewater for irrigation due to exceeding the maximum admissible concentrations for contaminants has some negative effects on corps, soil, and groundwater (Aydin et al. 2015; Belhaj et al. 2015). While numerous papers have been conducted to understand the impact of wastewater on groundwater resources (Alslaibi et al. 2017; Gotkowitz et al. 2016; Martins et al. 2017; Missimer et al. 2012; Siebe et al. 2018), many researchers have performed soil column experiments and HYDRUS-1D modeling to understand the impact of exclusively municipal wastewater on basic soil properties, absorption or movement of trace elements in soil, and the further possibility of their recharge into 
groundwater resources which causes pollution in the long term (Mahmoudi et al. 2018; Mojid et al. 2019; MamindyPajany et al. 2013).

Moreover, monitoring the mobility of trace elements and especially heavy metals (HM) in the soil is important because once they release into the soil-subsurface environment, they cannot be degraded (Berkowitz et al. 2014). If their levels are above the defined standard limits and can reach groundwater through leaching, it can endanger public health, because from the global standpoint, nearly 1.5 billion people depend upon groundwater for their drinking water supply and, in the absence of drinking water, people are bound to use pond water which hastens various types of waterborne diseases. Approximately, one-sixth of the world's population does not have access to clean drinking water which makes us pay more attention to this issue (Eslamian and Eslamian 2017). For instance, the presence of arsenic in groundwater poses the greatest health risk to humans due to the direct ingestion of arsenic-contaminated well waters, compared to its presence in rainwater or surface waters. This is all the more important given the fact that arsenic does not alter any of the physical properties of water (taste, color, and odor); it takes years for the symptoms of the related disease to appear and in most cases is fatal (Ahuja 2008). Also, about 300 million people worldwide are exposed to arsenic contamination in their drinking water and food supplies (Fares and Singh 2020). As a result, not only arsenic, as an example, but also the behavior and mobility of other trace elements in soil should be studied.

Nazarabad city with the area of $576 \mathrm{~km}^{2}$ and 150,000 population is located $85 \mathrm{~km}$ west of Tehran, inside the central zone of Iran. In this region, average annual rainfall, temperature, and humidity are $229.4 \mathrm{~mm}, 2.14{ }^{\circ} \mathrm{C}$, and $45 \%$, respectively. The climate of the region is also semi-arid. An examination of the soil of Nazarabad plain shows that it is chiefly coarse and fine-grained sediments that have been washed from the high northern areas during different geological eras and raining cycles and have been deposited subsequently in the southern regions. Moving from north to south, most sediments turn from coarse grained to fine grained, and the soil is very suitable for agriculture (especially irrigation farming) in terms of material and depth. The main water resources in Nazarabad are supplied by groundwater, which in the past was used in the form of manual wells and aqueducts (qanats) and in recent years in the form of deep and semideep wells. Additionally, the common type of aquifer in this area is often semi-permeable.

The aim of this study was to simulate the movement and transfer of trace elements in soil by creating a soil column experiment and numerical modeling, identifying soil self-purification, and examining the possibility of using treated municipal wastewater in irrigation without adversely affecting groundwater resources.

\section{Materials and methods}

\section{Soil sampling}

Soil sampling was carried out in April 2019. The soil samples were randomly taken from 12 different points at a depth of 40 to $60 \mathrm{~cm}$ from agricultural lands that have been irrigated or flooded with the treated wastewater (Fig. 1). Then, to obtain one representative soil sample, all the 12 soil samples were mixed together. In the following, the mixed soil was air-dried, sieved (less than $2 \mathrm{~mm}$ according to ASTM D6913 standard (ASTM-International 2014)), and homogenized. Table 1 shows the physico-chemical characteristics of the representative soil sample. Also, the texture of the representative soil sample was sandy based on the Udden-Wentworth grade scale for grain size (Douglas and McConchie 1994). X-ray diffraction (XRD) analysis detected quartz $\left(\mathrm{SiO}_{2}\right)$, calcite $\left(\mathrm{CaCO}_{3}\right)$, and albite $\left(\mathrm{NaAlSi}_{3} \mathrm{O}_{8}\right)$ as existing major minerals in the representative soil sample. Illite $\left(\left(\mathrm{K}, \mathrm{H}_{3} \mathrm{O}\right) \mathrm{Al}_{2} \mathrm{Si}_{3} \mathrm{AlO}_{10}(\mathrm{OH})_{2}\right)$, orthoclase $\left(\mathrm{KAlSi}_{3} \mathrm{O}_{8}\right)$, chlorite $\left((\mathrm{Mg}, \mathrm{Fe})_{6}(\mathrm{Si}, \mathrm{Al})_{4} \mathrm{O}_{10}(\mathrm{OH})_{8}\right)$, and dolomite $\left(\mathrm{CaMg}\left(\mathrm{CO}_{3}\right)_{2}\right)$ were available as minor minerals in the so-called sample.

\section{Wastewater sampling and characteristics of treated wastewater}

Nazarabad municipal wastewater treatment plant is located in Nazarabad city at the west of Alborz province. This newly established treatment plant includes an extended aeration activated sludge system. A total amount of 30 liters of effluent from the treatment plant was sampled and transported to hydro-chemistry laboratory under standard conditions. Acidity $(\mathrm{pH})$, electrical conductivity (EC), total dissolved solids (TDS), salinity (Sal), and temperature (T) were the five in situ parameters measured by $\mathrm{pH}$ meter and multi-parameter

Table 1 Physico-chemical characteristics of the representative soil sample

\begin{tabular}{|c|c|c|}
\hline Parameter & Amount & \\
\hline Porosity (\%) & 38 & \multirow{9}{*}{97.57} \\
\hline Bulk density $\left(\mathrm{g} / \mathrm{cm}^{3}\right)$ & 1.81 & \\
\hline $\mathrm{pH}$ & 8.31 & \\
\hline $\mathrm{EC}(\mu \mathrm{S} / \mathrm{cm})$ & 472 & \\
\hline Effective size $\left(D_{10}\right)(\mathrm{mm})$ & 0.11 & \\
\hline \multirow[t]{4}{*}{ Sand $(\%)$} & $\begin{array}{l}\text { Very coarse sand }(\% 13.08) \\
\text { Coarse sand }(\% 16.97)\end{array}$ & \\
\hline & Medium sand (\%20.63) & \\
\hline & Fine sand (\%34.38) & \\
\hline & Very fine sand (\%12.18) & \\
\hline Silt and clay (\%) & 2.43 & \\
\hline
\end{tabular}


Fig. 1 Agricultural lands that have been irrigated or flooded with the treated wastewater
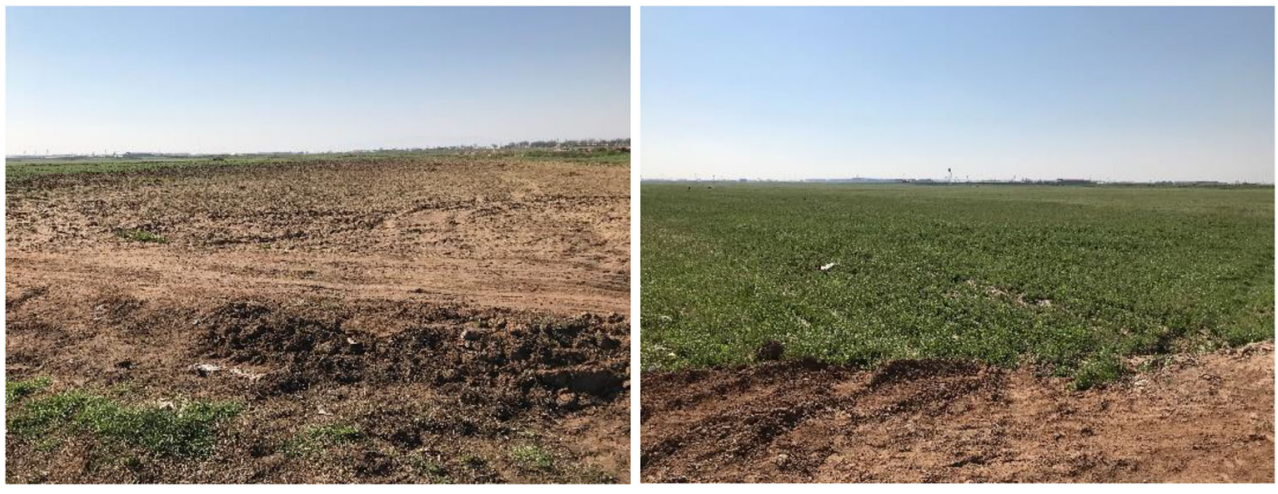

devices. The former effluent outlet (channel), with the specific UTM coordinates of 0461471 (longitudinal) and 3977448 (latitudinal), was located at an altitude of $1181 \mathrm{~m}$. Figure 2 represents the former effluent outlet in three different seasons of winter, spring, and summer. The mentioned outlet is now closed due to the farmers' dissatisfaction because the transferred wastewater through the channel was mainly used for irrigation purposes despite its polluting effect. For some time now, the treated wastewater has been released into a long pond near the treatment plant which is also close to the residential area (Fig. 3). Table 2 illustrates the characteristics of treated municipal wastewater sampled from inside the Nazarabad treatment plant before releasing into the pond.

\section{Soil column design and filling}

Column experiment recreates field conditions well and is appropriate to appraise the long-term release of chemical constituents from soil into the water bodies (Naka et al. 2016). Among the various materials used to make laboratory columns, three types, acrylic, glass, and stainless steel, are the most common. Originally, one plexiglass (acrylic) column with specified height of $45 \mathrm{~cm}$ and inner diameter of $5 \mathrm{~cm}$ was designed and built. Plexiglass columns do not react with soluble materials, have relatively good resistance, and are available in different diameters (Lewis and Sjöstrom 2010; Weihermüller et al. 2007). In order to monitor changes continuously, in addition to the end output of the column, three

Table 2 Characteristics of treated municipal wastewater sampled from inside Nazarabad treatment plant and recommended Iranian standard limits for artificial recharge of aquifer

\begin{tabular}{|c|c|c|c|c|c|}
\hline & Parameter & Value & Method/device & Unit & $\begin{array}{l}\text { Standard limit } \\
(\mathrm{mg} / \mathrm{l})\end{array}$ \\
\hline \multirow[t]{5}{*}{ Physico-chemical parameters } & $\mathrm{T}$ & 27 & Multi-parameter and $\mathrm{pH}$ meter & Centigrade & - \\
\hline & Sal & 0.3 & Multi-parameter & - & _- \\
\hline & $\mathrm{EC}$ & 618 & Multi-parameter & $\mu \mathrm{S} / \mathrm{cm}$ & _ \\
\hline & TDS & 308 & Multi-parameter & $\mathrm{mg} / \mathrm{l}$ & - \\
\hline & $\mathrm{pH}$ & 7.55 & $\mathrm{pH}$ meter & - & $5-9$ \\
\hline \multirow[t]{8}{*}{ Major ions (anions and cations) } & $\mathrm{Na}^{+}$ & 109 & ICP-MS & $\mathrm{mg} / 1$ & - \\
\hline & $\mathrm{K}^{+}$ & 12.41 & ICP-MS & $\mathrm{mg} / 1$ & _- \\
\hline & $\mathrm{Ca}^{2+}$ & 40.66 & ICP-MS & $\mathrm{mg} / \mathrm{l}$ & _- \\
\hline & $\mathrm{Mg}^{2+}$ & 25.72 & ICP-MS & $\mathrm{mg} / 1$ & 100 \\
\hline & $\mathrm{CO}_{3}{ }^{2-}$ & 0.0 & Titration & $\mathrm{mg} / 1$ & _ \\
\hline & $\mathrm{HCO}_{3}^{-}$ & 250.1 & Titration & $\mathrm{mg} / 1$ & _- \\
\hline & $\mathrm{SO}_{4}{ }^{2-}$ & 172.78 & Turbidity meter & NTU & 400 \\
\hline & $\mathrm{Cl}^{-}$ & 102.95 & Argentometric & $\mathrm{mg} / \mathrm{l} \mathrm{Cl}{ }^{-}$ & 600 \\
\hline \multirow[t]{6}{*}{ Pollution indicators } & BOD5 & 10 & Respirometric & $\mathrm{mg} / \mathrm{l} \mathrm{O}_{2}$ & 30 \\
\hline & $\mathrm{COD}$ & 35 & Closed reflux titrimetric & $\mathrm{mg} / \mathrm{l} \mathrm{O}_{2}$ & 60 \\
\hline & $\mathrm{NO}_{3}^{-}$ & 43 & Brucine & $\mathrm{mg} / 1 \mathrm{NO}_{3}^{-}$ & 10 \\
\hline & $\mathrm{PO}_{4}^{3-}$ & 1.55 & Stannous chloride & $\mathrm{mg} / \mathrm{PO}_{4}{ }^{3-}$ & 6 \\
\hline & Total coliforms & 2 & Multiple tube technique & MPN/100 ml & 1000 \\
\hline & Fecal coliforms & 2 & Multiple tube technique & MPN/100 ml & 400 \\
\hline
\end{tabular}



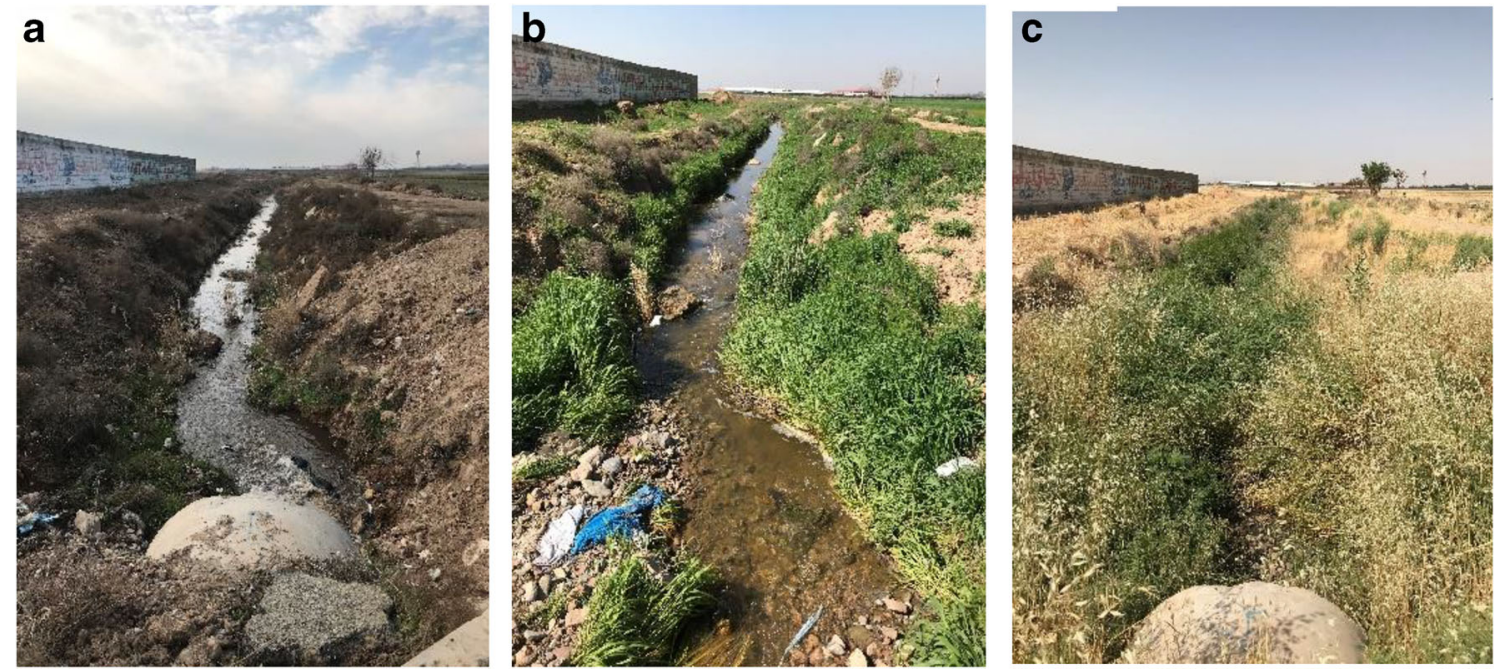

Fig. 2 The former effluent outlet (channel) in winter (a), spring (b), and summer (c)

additional output holes with a diameter of $0.6 \mathrm{~mm}$ with regular and equal distances $(15 \mathrm{~cm})$ were embedded in the body of the column at $7.5,22.5$, and $37.5 \mathrm{~cm}$. At the end and top of the column, two perforated plexiglass boards were installed. The end board was inseparable and enclosing, while the top board was detachable and placed on the surface of the soil. Perforated boards are used to prevent disturbing factors of sidewall flow (Corwin 2000; Sentenac et al. 2001) and fingering (Selker et al. 1999; Glass et al. 1989). For convenience, laboratory valves were installed at the top and bottom of the column to make it possible to control the entry and exit of effluent and thus to measure parameters such as hydraulic conductivity.

The entire column and its accessories were weighted before filling with the representative soil. To fill the plexiglass column using dry (or damp) packing method (Bégin et al. 2003; Communar et al. 2004), the soil was gradually poured into the column and compacted with a plastic rod (Oliviera et al. 1996). In this method, the height of the soil inside the column

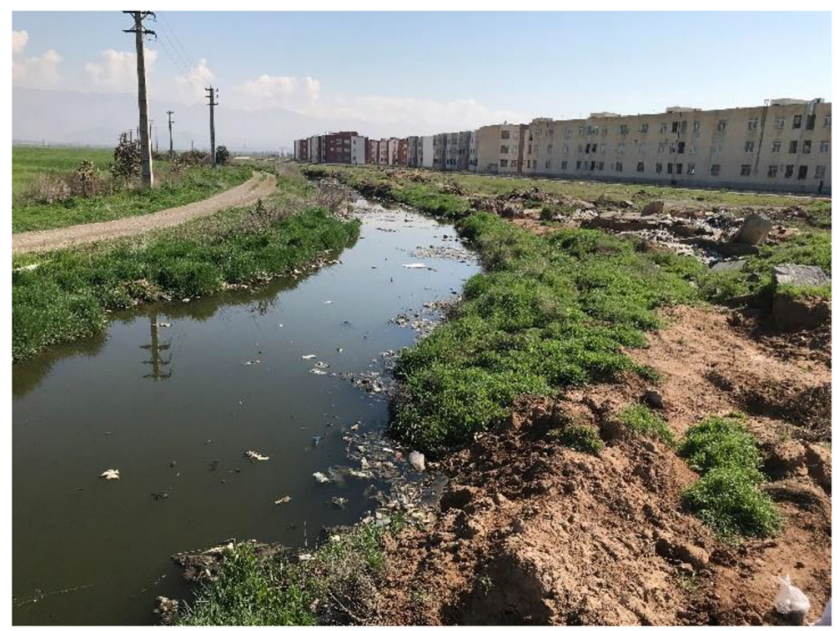

Fig. 3 Proximity of residential area and effluent pond should be a maximum of $1 \mathrm{~cm}$ per embankment. This procedure is continued until the column is filled with compacted soil. Prior to filling, two layers of sterile gauze were placed at the end of the column (more precisely on the lower latticed plexiglass board) to prevent soil from spilling out of the end hole. The bulk density which was used for filling is $1.81 \mathrm{gr} /$ $\mathrm{cm}^{3}$.

\section{Measuring parameters}

Before starting the experiment, the porosity $\left(\theta_{P V}\right)$ parameter was measured by using a cylindrical container with specified dimensions. This measurement was performed three times and finally its mean value was considered. In this way, first, the container was weighed once before and after filling with the soil, and then it was placed in a water pan to get soaked completely. Then, after re-weighing, the difference between the weight of dry and wet (saturated) soil was obtained and divided by the volume of the container. Before measuring the porosity, the soil must be fully compacted inside the chamber. The bulk density parameter was calculated by dividing the unsaturated weight (dry soil weight) by the volume of the cylindrical container (total volume). This parameter, like porosity, is averaged after several measurements (Table 1).

The hydraulic conductivity $(K)$ parameter was measured for several times, and finally the average value of $252.73 \mathrm{~cm} /$ day was considered. In this study, the falling head permeability test was used to determine the hydraulic conductivity of soil because it was easier to measure in the laboratory. To do this, the treated wastewater that had previously been poured into a standpipe entered the column from the bottom by opening the embedded laboratory valve and exited from above and was poured into another container. The change in water height (hydraulic head) was recorded in the standpipe as well as the corresponding time, and by placing this 
information in the following formula, hydraulic conductivity was obtained (Delleur 1999):

$K=\frac{r^{2} L}{R^{2} t} \ln \frac{h_{1}}{h_{2}}$

where $r^{2}$ and $R^{2}$ are the radii of the standpipe and of the specimen, respectively, $L$ is the length of the specimen, and $h_{1}$ and $h_{2}$ are the heads at the beginning and at a later time $t$.

The above formula simplifies the following formula (Das 1985):

$K=2.303 \frac{a L}{A t} \log _{10} \frac{h_{1}}{h_{2}}$

where $a$ and $A$ are the cross-sectional area of the standpipe and of the specimen, respectively.

\section{Soil column experiment}

The laboratory setup includes a peristaltic pump, a treated wastewater reservoir which maintains a hydraulic constant head, a plexiglass column, and scaled beakers for collecting effluent samples. The experiment was performed using a peristaltic pump at the lowest flow rate of $3.075 \mathrm{ml} / \mathrm{min}$ to provide maximum time for soil and wastewater interactions. In this regard, the plan of $12 \mathrm{~h}$ wetting and $12 \mathrm{~h}$ drying cycle was selected. During this 6-day period experiment, constant pressure head and seepage face boundary conditions were established above and below the column, respectively.

Sampling of effluent from the column is based on pore volume (PV), which is the product of the volume of the column (at the corresponding height) by soil porosity. In simpler terms, pore volume is equivalent to the volume of soil filled with water (Kirkham and Powers 1972). All the calculation results of pore volumes for each output hole are listed in Table 3. As mentioned earlier, there are 4 output holes in the column: 3 holes in the body $(0.6 \mathrm{~mm}$ in diameter at regular intervals) and 1 hole at the end of the column. In order to sample each hole, the openings of the other three holes were closed. For example, when sampling the first hole at the top (having a volume equal to $P V_{1}$ as shown in Table 3), the bottom three holes were closed so that the exchanged wastewater only came out of the open hole; or similarly, for sampling from the second hole, the openings of the other three holes were blocked so that only the second hole could be sampled. In this way, small samples of soil water were taken from the column at different depths. This was easier to do for the end hole because it had a laboratory valve. Also, the sampling order was as follows: in each series, the first, the second, the third, and the fourth hole were completely sampled, respectively, and then the next series of collecting sample began. Finally, sampling was completed in 20 series of sampling from each hole ( 80 samples from the column in total), and the output samples of all 5 pore volumes taken in succession from each hole were combined (e.g., PV1 to PV5 (PV1-5) of the first hole or PV10 to PV15 (PV10-15) of the third hole were mixed together). This means that, finally, 4 samples from each hole and a total of 16 samples from the column were analyzed for physico-chemical parameters, major ions (i.e., cations and anions), and trace elements. The findings will be described later in "Laboratory analysis of wastewater". Approximately, 171 of municipal wastewater exchanged from the soil column. At every stage of sampling, physico-chemical parameters such as $\mathrm{EC}(\mu \mathrm{S} / \mathrm{cm}), \mathrm{pH}$, TDS $(\mathrm{mg} / \mathrm{l}), \mathrm{T}\left({ }^{\circ} \mathrm{C}\right)$, and salinity were immediately measured on site using portable devices. Moreover, the trace element samples after acidification $(\mathrm{pH}$ $<2.0$ by adding HNO3) were sent to the laboratory for inductively coupled plasma mass spectroscopy (ICP-MS) analysis, and other parameters including $\mathrm{SO}_{4}^{2-}, \mathrm{HCO}_{3}^{-}, \mathrm{CO}_{3}^{2-}, \mathrm{Cl}^{-}$, $\mathrm{Ca}^{2+}$, and $\mathrm{Mg}^{2+}$ were also measured. The principles of keeping samples in the laboratory were also fully observed; during the whole test, the samples taken were stored in the refrigerator at the standard temperature of $4{ }^{\circ} \mathrm{C}$. At the end of the recharge experiment, the plexiglass column was cut into three equal $15 \mathrm{~cm}$ sections, and the soil in each section was investigated by ICP-MS analysis.

\section{HYDRUS-1D software}

The basics of HYDRUS-1D goes back to the original work of van Genuchten (Šimůnek et al. 2012), but the main development of this software took place in 2008 with the release of version 4 (Šimůnek and van Genuchten 2008; Šimůnek et al. 2016). In this investigation, version 4.17.0140 of HYDRUS-
Table 3 Calculation of pore volumes assigned to each specific height of the soil column using measured porosity in the sedimentology laboratory

\begin{tabular}{lllll}
\hline PV number & Height $(\mathrm{cm})$ & Porosity $\left(\theta_{P V}\right)$ & Column volume $\left(=\Pi \mathrm{r}^{2} \mathrm{~h}\right)$ & PV value $(\mathrm{ml})$ \\
\hline PV1 & $0-7.5$ & 0.38 & 147.18 & 55.93 \\
PV2 & $7.5-22.5$ & 0.38 & 441.56 & 167.79 \\
PV3 & $22.5-37.5$ & 0.38 & 735.93 & 279.66 \\
PV4 & $37.5-45$ & 0.38 & 883.12 & 335.59 \\
Total wastewater passing through column after each exchange & $\mathbf{8 3 8 . 9 7}$ \\
\multicolumn{2}{l}{ Total wastewater passing through column after 20 exchange } \\
\hline
\end{tabular}


1D was used to simulate the transfer of heavy metals in the soil (Radcliffe and Šimůnek 2010). This software can be downloaded from the pc-progress site at https://www.pcprogress.com/en/default.aspx.

The Richards equation is a basic equation of water movement in unsaturated soil, and its so-called "potential" form (1) is described as (Novák and Hlaváčiková 2019):

$c\left(h_{w}\right) \frac{\partial h_{w}}{\partial t}=\frac{\partial}{\partial z}\left[k\left(h_{w}\right) \frac{\partial h_{w}}{\partial z}\right]+\frac{\partial k\left(h_{w}\right)}{\partial z} \pm S(z, t)$

where $\mathrm{c}\left(h_{w}\right)$ is specific soil-water capacity $\left[L^{-1}\right], h_{w}$ is the water pressure head [L], $t$ is time [T], $k$ is the unsaturated hydraulic conductivity function $\left[L T^{-1}\right], z$ is the spatial coordinate [L], and $S$ is water outflow (negative sign) or water inflow (positive sign) from or to soil volume under consideration or in other words the sink term $\left[L^{3} L^{-3} T^{-1}\right.$ or $\left.L T^{-1}\right]$.

In simulation models of one-dimensional water movement in homogeneous soils and under isothermal conditions, a modified form of the Richards Eq. (2) is often used which considers that the air phase plays an insignificant role in the liquid flow process and that water flow due to thermal gradients can be ignored. The governing one-dimensional uniform water flow equation is described as (Phogat et al. 2020; Šimůnek et al. 2013):

$\frac{\partial \theta\left(h_{w}\right)}{\partial t}=\frac{\partial}{\partial z}\left[k\left(h_{w}\right)\left(\frac{\partial h_{w}}{\partial z}+1\right)\right]-S(z)$

where $\theta$ is the volumetric soil-water content $\left[L^{3} L^{-3}\right.$ or -$]$.

In this study, numerical modeling was done in three steps: firstly, plotting breakthrough curve (BTC); secondly, parameter optimization by HYDRUS inverse modeling; and thirdly, prediction modeling. The obtained parameters of the first two steps were requisite to reach the final simulation (third step). In step one, after conducting a tracer test, BTC gives out the value for longitudinal dispersivity $\left(D_{\nu}\right)$. This parameter is used to optimize and extract adsorption isotherm coefficients $\left(K_{d}\right.$ and $\beta$ ) in step two. In the last step, 5-year prediction modeling was performed in HYDRUS-1D by using mentioned optimized parameters.

\section{Results and discussions}

\section{Laboratory analysis of wastewater}

\section{Physico-chemical parameters}

In general, it can be understood from Fig. 4 that all physicochemical parameters have unrelated trends with depth; however, their final value has increased compared to their initial value in the primary wastewater. As can be seen from comparing EC and TDS charts, their change curves are very similar. Neither of these two parameters has changed much, with the minimum and maximum values of 618 and $655 \mu \mathrm{S} / \mathrm{cm}$ for EC and 308 and $327 \mathrm{mg} / \mathrm{l}$ for TDS. Numbers of 618 and 308 belong to the pre-experiment wastewater. The $\mathrm{pH}$ of the incoming wastewater was 7.55, and at the end of the experiment, the $\mathrm{pH}$ value increased by 0.49 (8.04-7.55= 0.49 ). The range of $\mathrm{pH}$ changes in the effluent samples was between 8.25 at the beginning and 8.04 at the end of the recharge, which indicates that the effluent becomes more acidic as it passes through the soil. Also, salinity of the input and all output wastewater samples showed a constant value of 0.3 throughout the soil column experiment, so the trend chart of this parameter has not been traced.

\section{Major ions}

In all soil water samples collected from output holes as explained in "Soil column experiment", the concentration of the major cations ( $\mathrm{Na}, \mathrm{K}, \mathrm{Mg}$, and $\mathrm{Ca}$ ) has increased compared to their concentrations in the primary wastewater. The concentration trends of these four cations are not very related to depth. Moreover, the range of concentration changes is low for each cation; for instance, during the entire test period, the difference between the highest and the lowest concentration for potassium ion $\left(K^{+}\right)$was only $6.56 \mathrm{mg} / \mathrm{l}$. This value was equal to $10.23,13.47$, and $14 \mathrm{mg} / \mathrm{l}$ for $\mathrm{Ca}, \mathrm{Mg}$, and $\mathrm{Na}$, respectively. Of all these cations, $\mathrm{Na}$ had the highest concentration in effluent during the entire recharge experiment; hence it is the most abundant major cation in effluent (Fig. 5).

In addition to cations, changes in the concentration of three major anions $\left(\mathrm{SO}_{4}^{2-}, \mathrm{Cl}\right.$, and $\left.\mathrm{HCO}_{3}^{-}\right)$have also been analyzed in this experiment (Fig. 6). The concentration of sulfate and bicarbonate, unlike chloride, has decreased in the output samples compared to the primary effluent. Although $\mathrm{HCO}_{3}^{-}$shows a more regular trend of change, its change in concentration is irrelevant to depth, just similar to $\mathrm{SO}_{4}^{2-}$ and $\mathrm{C} \digamma$. Needless to say that nitrate $\left(\mathrm{NO}_{3}^{-}\right)$was detected upper than the maximum permissible limit (43 mg/l $\mathrm{NO}_{3}^{-}$) in the primary wastewater (Table 2). Nitrate can be transported from agricultural lands by both surface runoff and subsurface leaching because of the high mobility in the soil profile (Selim 2013) which seriously induces groundwater contamination (National Research Council 1984).

\section{Trace elements (TEs)}

The 10 most important detected trace elements, hereafter referred to as TEs, in the pre- and post-experiment wastewater samples are $\mathrm{As}, \mathrm{Ba}, \mathrm{Cr}, \mathrm{Cu}, \mathrm{Mo}, \mathrm{Ni}, \mathrm{Pb}, \mathrm{Rb}, \mathrm{Sr}$, and $\mathrm{Zn} . \mathrm{Cd}$ and $\mathrm{Tl}$ have also been detected but their values were minor and under the detection limit. Table 4 depicts the results for ICP-MS analysis of TEs in primary wastewater and their 
Fig. 4 Changes in physicochemical parameters of soil column effluent samples. PV1-5 refers to the 1 st to 5 th sampled pore volumes (PV1 to PV5) from the first $(7.5 \mathrm{~cm})$, second $(22.5 \mathrm{~cm})$, third $(37.5 \mathrm{~cm})$, and fourth $(45 \mathrm{~cm})$ outputs separately

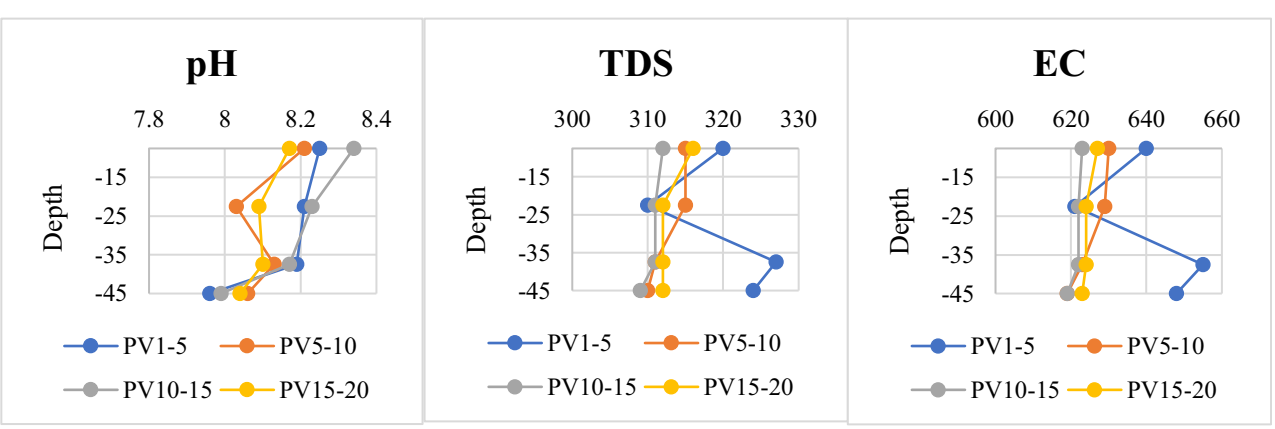

suggested standard limits for aquifer recharge along with the permissible standard announced by the FAO and WHO (FAO 2003; WHO 2006). According to the table, all the TEs in the treated municipal wastewater sample from the Nazarabad treatment plant are below the recommended standard for groundwater recharge. Figure 7 illustrates the changes in TE concentrations in effluent samples while performing the experiment. It is observable that, with the exception of As and $\mathrm{Sr}$, there is not a clear relationship between the TE concentration and depth of the soil column. Furthermore, only these two elements exhibit a regular decrease in concentration over time.

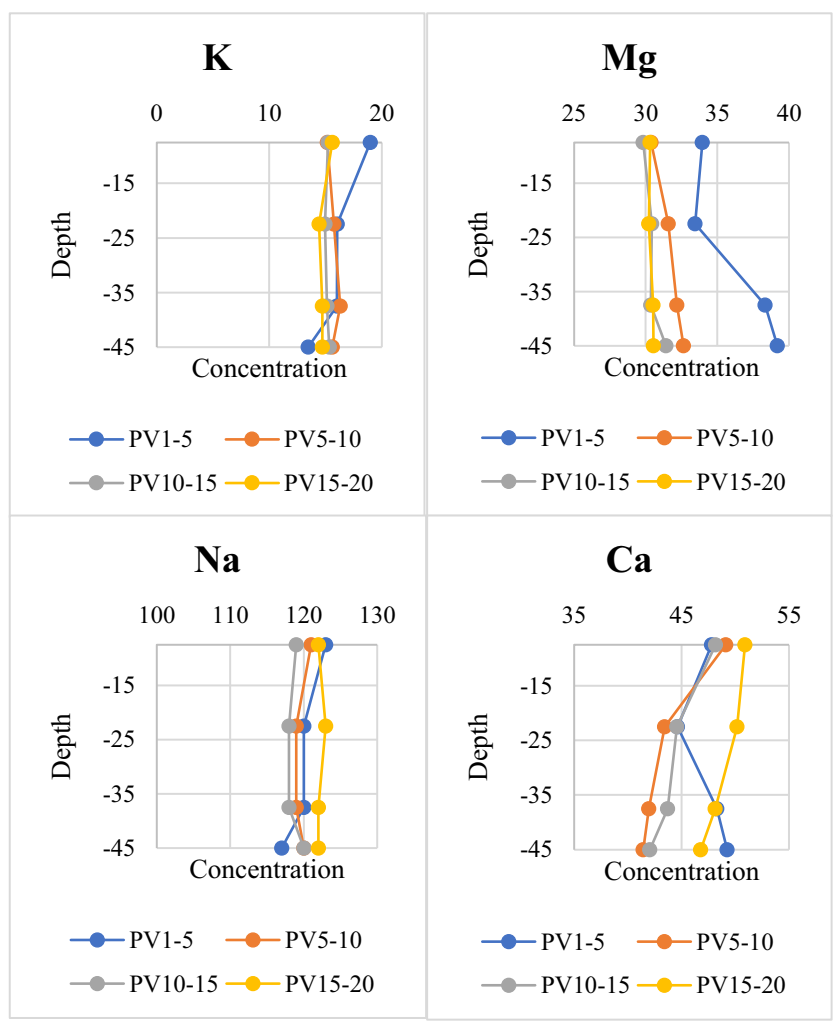

Fig. 5 Changes in cation concentrations of soil column effluent samples. PV5-10 refers to the 5th to 10th sampled pore volumes (PV5 to PV10) from the first, second, third, and fourth outputs separately

\section{Laboratory analysis of soil}

\section{Trace elements (TEs)}

On an ecological hazard basis, heavy metal/metalloid sequence in the soil is as follows: $\mathrm{Se}>\mathrm{Tl}>\mathrm{Sb}>\mathrm{Cd}>\mathrm{Hg}>$ $\mathrm{Ni}>\mathrm{Cu}>\mathrm{Cr}>\mathrm{As}>\mathrm{B}$ (Vodyanitskii 2013). Contrary to previous assumptions, it has been found that factors can enhance the mobility of these metals in the soil and, as a result, further leaching into groundwater (McBride 1995). Even complex pollution, caused by a variety of HMs, can exacerbate the contamination of individual heavy metals, for instance, $\mathrm{Cu}+$ $\mathrm{Pb}>\mathrm{Pb}>\mathrm{Cu}$ (Su et al. 2014). Soil is a natural filter, and its self-purification rate is a key factor in removing such metals and attenuating their migration rates to deeper parts of the soil (Keesstra et al. 2012; Plekhanova 2017). Otherwise, this can lead to health risks (Hussain and Qureshi 2020; Todd and Mays 2005).

Table 5 represents the concentrations of pre-soil TEs compared to the Iranian standards for alkaline soil. Based on these standards, the representative soil sample taken from the farmlands irrigated with treated urban wastewater is not polluted; however, it is rich in $\mathrm{Ba}$ and $\mathrm{Sr}$ which releasing them into recharging water and then their further transportation through soil and water might be potentially hazardous for groundwater protection over an extended period of irrigation. As it was previously mentioned, the post-experiment soil of $0-15,15$ 30 , and $30-45 \mathrm{~cm}$ height were analyzed for TEs using ICPMS analysis. Changes in the concentration of HMs in the soil in terms of height after the completion of recharge experiment and comparison with their initial amounts in the soil are shown in Fig. 8. In general, except $\mathrm{Ba}, \mathrm{Pb}$, and $\mathrm{Tl}$, the concentration of all TEs in the soil has decreased after the experiment compared to the primary soil. $\mathrm{Cd}$ is the only heavy metal that does not show any concentration change in the soil due to its low concentration in the soil of the area and the wastewater passing through it. Regarding this metal and $\mathrm{Tl}$, it can be said that, respectively, due to having a constant and very low concentration in the soil and the inability to extract the required coefficients, simulation of these metals has not been carried out. 
Fig. 6 Changes in anion concentrations of soil column effluent samples. PV10-15 refers to the 10th to 15th sampled pore volumes (PV10 to PV15) from the first, second, third, and fourth outputs separately

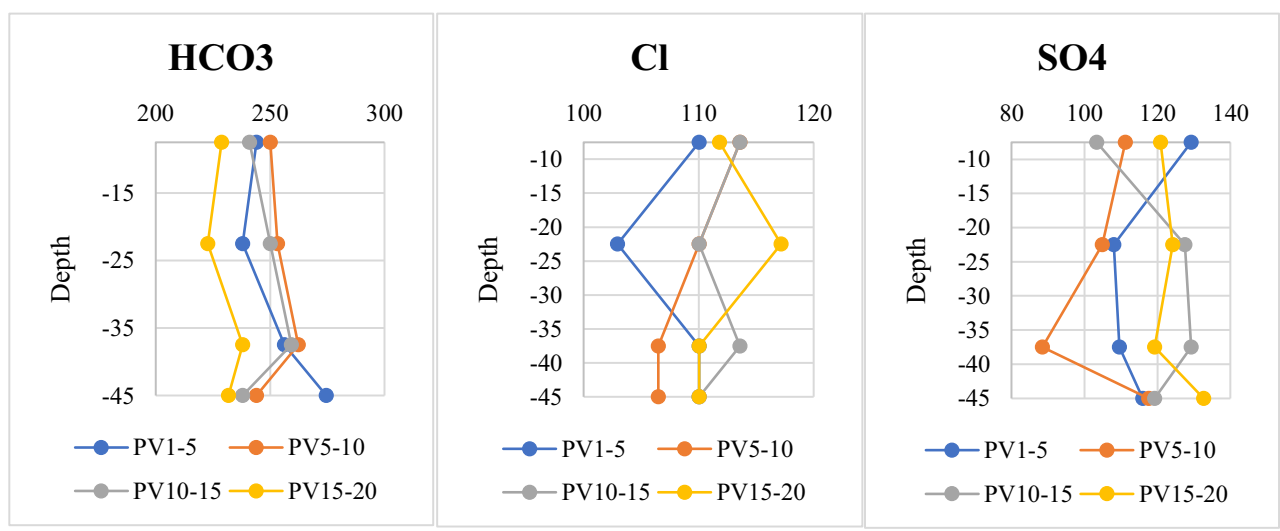

\section{Software studies}

\section{Plotting breakthrough curve (BTC) to obtain longitudinal dispersivity $\left(D_{l}\right)$ by using inverse method in HYDRUS-1D}

In simple and concise terms, a $B T C$ represents the relationship between the concentration of a tracer, mostly a salt, and time (Kirkham and Powers 1972; Novák and Hlaváčiková 2019). In this study, we have used potassium chloride as the tracer; therefore the influent wastewater was switched with 11 of $\mathrm{KCl}$ solution $(5390 \mu \mathrm{S} / \mathrm{cm})$. The EC of the solution leaching from the soil column was accurately measured in 20 volumes of $50 \mathrm{ml}$ by the multi-parameter device. The duration of solution sampling was also recorded per $50 \mathrm{ml}$ volume. In other words, 20 samples of $50 \mathrm{ml}$ which was equivalent to the total volume of the input $\mathrm{KCl}$ solution were sampled at the end of the tracer test. The gained experimental values of EC were given to the

Table 4 ICP-MS analysis results of the trace elements in primary wastewater and their suggested standard limits for aquifer recharge (Iranian Department of Environment 2019) and irrigation (FAO 2003; WHO 2006)

\begin{tabular}{llll} 
Heavy metal & Value (ppb) & Standard limit \\
\cline { 3 - 4 } & & Department of Environment & FAO/WHO \\
\hline $\mathrm{As}$ & 7.55 & 100 & 100 \\
$\mathrm{Ba}$ & 30.56 & 1000 & - \\
$\mathrm{Cd}$ & $<1$ & 100 & 10 \\
$\mathrm{Cr}$ & 9.8 & $1000-2000$ & 100 \\
$\mathrm{Cu}$ & 2.24 & 1000 & 200 \\
$\mathrm{Mo}$ & 6.16 & 10 & 10 \\
$\mathrm{Ni}$ & 2.02 & 2000 & 200 \\
$\mathrm{~Pb}$ & $<0.1$ & 1000 & 5000 \\
$\mathrm{Rb}$ & 11.02 & - & - \\
$\mathrm{Sr}$ & 792 & - & - \\
$\mathrm{Tl}$ & $<0.1$ & - & - \\
$\mathrm{Zn}$ & 4.47 & 2000 & 2000 \\
\hline
\end{tabular}

model as input data to plot the BTC using inverse method of HYDRUS-1D. Finally, parameter of longitudinal dispersivity $\left(D_{\nu}\right)$ was obtained from the BTC: $14.81 \mathrm{~m}$ which is suitable for sandy soils. Achieving a reliable value for this parameter is fundamental because it is used in the subsequent modeling (Bromly et al. 2007). Clay content followed by column diameter is the most important factor controlling dispersivity (Bromly et al. 2007).

\section{Obtaining adsorption isotherm coefficients of $K_{d}$ and $\beta$ for each metal separately using inverse method}

In this step, as the previous one, the inverse method is used to obtain the required parameters. Table 6 demonstrates the obtained adsorption isotherm coefficients $\left(K_{d}\right.$ and $\beta$ ) for various TEs together with their standard deviation and confidence limits. To obtain these coefficients, the dispersivity parameter obtained from the previous step and the data related to the concentrations present in different depths of the soil after recharge experiment have been used (Radcliffe and Šimůnek 2010).

Five-year period modeling of the impact of heavy metals (HMs) in treated municipal wastewater on groundwater resources in Nazarabad plain

The third and final step of prediction modeling was performed by entering some important input data including soil depth of $20 \mathrm{~m}$ and a simulation duration of 5 years; also, the corresponding boundary conditions for the upper and lower boundaries were considered constant pressure head and free drainage, respectively. Figure 9 and Table 7 illustrate the final results for this simulation.

According to the results, three metals including molybdenum $(\mathrm{Mo})$, chromium $(\mathrm{Cr})$, and rubidium $(\mathrm{Rb})$ have respectively the highest mobility and are balanced in a shorter time. In contrast, the other three metals involving copper $(\mathrm{Cu})$, arsenic (As), and lead $(\mathrm{Pb})$ have the least mobility (the most absorption by soil) and are slower to become balanced. The 
Fig. 7 The changes in trace element concentrations of effluent samples while performing the experiment. PV15-20 refers to the 15 th to 20 th sampled pore volumes (PV15 to PV20) from the first, second, third, and fourth outputs separately
Table 5 Concentrations of presoil trace elements compared to the Iranian standards for alkaline soil (Iranian Department of Environment 2019)

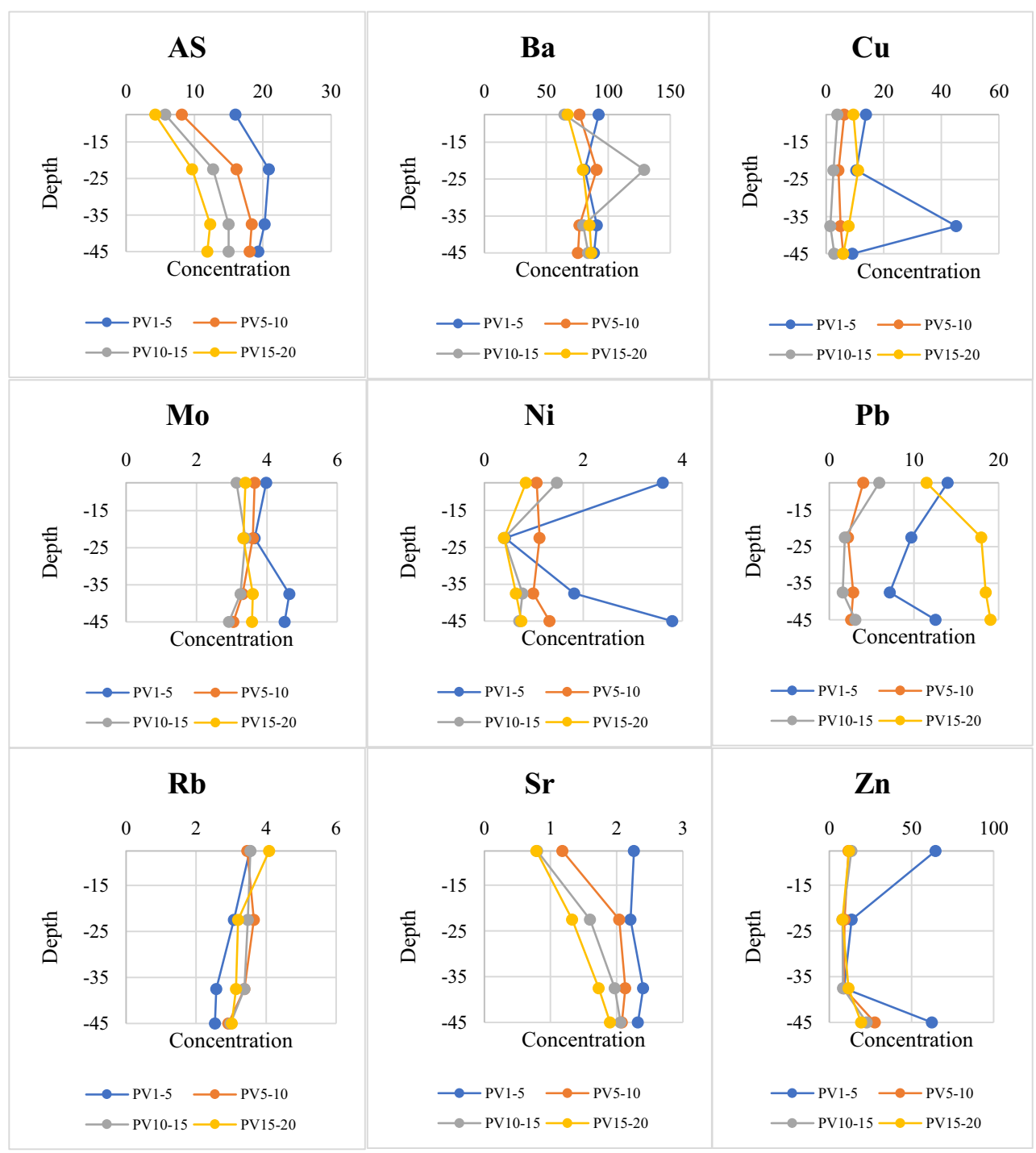

\begin{tabular}{|c|c|c|c|c|}
\hline \multirow{2}{*}{$\begin{array}{l}\text { Heavy } \\
\text { metal }\end{array}$} & \multirow{2}{*}{$\begin{array}{l}\text { Value } \\
\text { (ppm) }\end{array}$} & \multicolumn{3}{|c|}{ Standard limit for soils with $\mathrm{pH}>7$} \\
\hline & & $\begin{array}{l}\text { Groundwater recharge } \\
\text { protection }\end{array}$ & $\begin{array}{l}\text { Environmental } \\
\text { conservation }\end{array}$ & $\begin{array}{l}\text { Human } \\
\text { (agriculture) }\end{array}$ \\
\hline As & 10.4 & 100 & 17 & 40 \\
\hline $\mathrm{Ba}$ & 415 & 2000 & 500 & 600 \\
\hline $\mathrm{Cd}$ & 0.2 & 20 & 3.9 & 5 \\
\hline $\mathrm{Cr}$ & 51 & $100-3000$ & $0.4-64$ & $2-110$ \\
\hline $\mathrm{Cu}$ & 26 & 1500 & 63 & 200 \\
\hline Mo & 1.2 & 100 & 4 & 40 \\
\hline $\mathrm{Ni}$ & 26 & 600 & 50 & 110 \\
\hline $\mathrm{Pb}$ & 8 & 300 & 300 & 75 \\
\hline $\mathrm{Rb}$ & 54 & - & - & - \\
\hline $\mathrm{Sr}$ & 1012 & - & - & - \\
\hline $\mathrm{Tl}$ & 0.26 & 4 & 0.9 & 5 \\
\hline $\mathrm{Zn}$ & 55 & 3000 & 200 & 500 \\
\hline
\end{tabular}




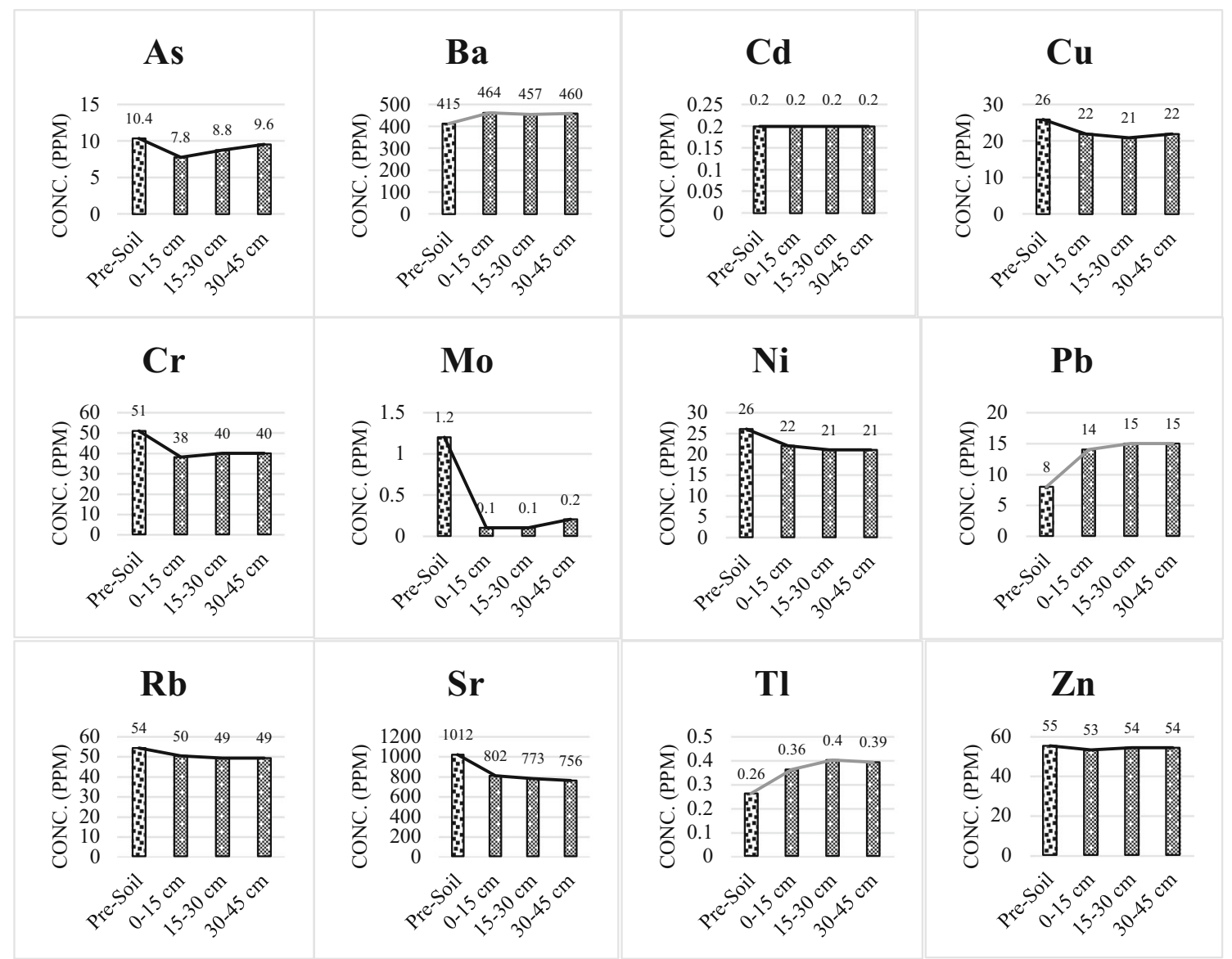

Fig. 8 Changes in the concentration of HMs in the soil after the completion of recharge experiment and comparison with their initial amount

other heavy metals are somewhere between these two groups. The highest mobility indicates the lowest adsorption by the soil, and vice versa. Reaching the equilibrium rate for the rare elements during 1825 days ( $=5$ years) was as follows: Mo $>$ $\mathrm{Cr}>\mathrm{Rb}>\mathrm{Zn}>\mathrm{Ni}>\mathrm{Ba}>\mathrm{Sr}>\mathrm{Pb}>\mathrm{As}>\mathrm{Cu}$. In general, the diagrams show the leaching phenomenon that occurred at the beginning of the recharge; and sometime after the continuation of the recharge due to counterbalancing in the system, the concentration of ions in the effluent, and in other words the dissolution rate, remained constant until the end of 5 years. By increasing the time period of the model (more than 1825 days), it is possible to reduce the dissolution of metals after a period of constant stability and balance of the system.

The result of the 5-year prediction modeling shows a good correlation with real conditions; this means that just as molybdenum is highly mobile in nature, or that lead, copper, and other metals are less mobile, modeling results have also shown the same. Low mobility and high mobility metals in nature are among the low mobility and high mobility metals in the simulation results, respectively. The numbers for the correlations for some of the elements are as follows: Mo $\left(R^{2}=\right.$ $0.99677, R M S E=0.1257 \mathrm{E}+00), \operatorname{Sr}\left(R^{2}=0.72938, R M S E=\right.$ $0.4323 \mathrm{E}+01), \mathrm{Cu}\left(R^{2}=0.71535, R M S E=0.1287 \mathrm{E}+01\right)$, and As $\left(R^{2}=0.60524, R M S E=0.4620 \mathrm{E}+00\right)$.
In general, there are six factors affecting TE mobility and transport: soil $\mathrm{pH}$, chemical speciation, soil organic matter, fertilizers and soil amendments, redox potential, and finally clay content and soil structure. Among these, $\mathrm{pH}$ is the main variable controlling the solubility, mobility, and transport of TEs because it influences many soil processes including TE sorption; in fact, sorption is $\mathrm{pH}$ dependent and increases as $\mathrm{pH}$ increases. In sandy soils, such as the soil of this study, ion sorption increases by $2-10$ fold per one unit increase in $\mathrm{pH}$ (Carrillo-González et al. 2006). Under normal soil pH conditions, if the organic matter decomposes and forms a complex with HMs, the concentration of HMs in the soil solution increases. Thus, mobility and thereafter leaching rates increase; as a result, infiltration time is reduced. In contrast, the formation and accumulation of organic matter can retain HMs and reduce leaching rate as well as mobility through the soilsubsurface system (Berkowitz et al. 2014; Chu et al. 2014). As shown in Fig. 9, the dissolution of TEs after the start of irrigation with municipal wastewater has an increasing trend, and after several days of its onset (which varies for different elements), the dissolution rate has reached equilibrium; and this trend has continued until the end of 5 years. Based on Table 7, $\mathrm{Cu}$ was balanced in soil 16 times slower than Mo, and because $\mathrm{Cu}$ is less mobile and more likely to be trapped in 
Table 6 Obtained adsorption isotherm coefficients $\left(K_{d}\right.$ and $\beta$ ) for various trace elements using inverse method of HYDRUS-1D along with their standard deviation and confidence limits

\begin{tabular}{|c|c|c|c|c|c|}
\hline \multirow[t]{2}{*}{ Element } & \multirow[t]{2}{*}{ Variable } & \multirow[t]{2}{*}{ Value } & \multirow[t]{2}{*}{ S. E. coeff. } & \multicolumn{2}{|c|}{$95 \%$ confidence limits } \\
\hline & & & & Lower & Upper \\
\hline \multirow[t]{2}{*}{ As } & $\mathrm{K}_{\mathrm{d}}[\mathrm{ml} / \mathrm{g}]$ & $1.86 \mathrm{E}+01$ & $0.23923 \mathrm{E}+02$ & $-0.28536 \mathrm{E}+03$ & $0.32258 \mathrm{E}+03$ \\
\hline & $\beta[-]$ & $1.34 \mathrm{E}+00$ & $0.49702 \mathrm{E}+00$ & $-0.49773 \mathrm{E}+01$ & $0.76529 \mathrm{E}+01$ \\
\hline \multirow[t]{2}{*}{$\mathrm{Ba}$} & $\mathrm{K}_{\mathrm{d}}[\mathrm{ml} / \mathrm{g}]$ & $1.24 \mathrm{E}+01$ & $0.80356 \mathrm{E}+02$ & $-0.10087 \mathrm{E}+04$ & $0.10334 \mathrm{E}+04$ \\
\hline & $\beta[-]$ & $1.17 \mathrm{E}+00$ & $0.73696 \mathrm{E}+00$ & $-0.81948 \mathrm{E}+01$ & $0.10533 \mathrm{E}+02$ \\
\hline \multirow[t]{2}{*}{$\mathrm{Cr}$} & $\mathrm{K}_{\mathrm{d}}[\mathrm{ml} / \mathrm{g}]$ & $1.08 \mathrm{E}+01$ & $0.38076 \mathrm{E}+02$ & $-0.47295 \mathrm{E}+03$ & $0.49464 \mathrm{E}+03$ \\
\hline & $\beta[-]$ & $1.23 \mathrm{E}+00$ & $0.68699 \mathrm{E}+00$ & $-0.75030 \mathrm{E}+01$ & $0.99549 \mathrm{E}+01$ \\
\hline \multirow[t]{2}{*}{$\mathrm{Cu}$} & $\mathrm{K}_{\mathrm{d}}[\mathrm{mll} / \mathrm{g}]$ & $9.26 \mathrm{E}+00$ & $0.20608 \mathrm{E}+02$ & $-0.25258 \mathrm{E}+03$ & $0.27111 \mathrm{E}+03$ \\
\hline & $\beta[-]$ & $1.48 \mathrm{E}+00$ & $0.59941 \mathrm{E}+00$ & $-0.61332 \mathrm{E}+01$ & $0.90989 \mathrm{E}+01$ \\
\hline \multirow[t]{2}{*}{ Mo } & $\mathrm{K}_{\mathrm{d}}[\mathrm{mll} / \mathrm{g}]$ & $1.09 \mathrm{E}+01$ & $0.11781 \mathrm{E}+01$ & $-0.40472 \mathrm{E}+01$ & $0.25890 \mathrm{E}+02$ \\
\hline & $\beta[-]$ & $6.30 \mathrm{E}-01$ & $0.55672 \mathrm{E}-01$ & $-0.77367 \mathrm{E}-01$ & $0.13374 \mathrm{E}+01$ \\
\hline \multirow[t]{2}{*}{$\mathrm{Ni}$} & $\mathrm{K}_{\mathrm{d}}[\mathrm{ml} / \mathrm{g}]$ & $1.00 \mathrm{E}+01$ & $0.30812 \mathrm{E}+02$ & $-0.38148 \mathrm{E}+03$ & $0.40151 \mathrm{E}+03$ \\
\hline & $\beta[-]$ & $1.48 \mathrm{E}+00$ & $0.82833 \mathrm{E}+00$ & $-0.90462 \mathrm{E}+01$ & $0.12003 \mathrm{E}+02$ \\
\hline \multirow[t]{2}{*}{$\mathrm{Pb}$} & $\mathrm{K}_{\mathrm{d}}[\mathrm{ml} / \mathrm{g}]$ & $1.43 \mathrm{E}+01$ & $0.27675 \mathrm{E}+02$ & $-0.33737 \mathrm{E}+03$ & $\begin{array}{l}-0.33737 \mathrm{E}+ \\
03\end{array}$ \\
\hline & $\beta[-]$ & $1.26 \mathrm{E}+00$ & $0.60556 \mathrm{E}+00$ & $-0.64339 \mathrm{E}+01$ & $0.89546 \mathrm{E}+01$ \\
\hline \multirow[t]{2}{*}{$\mathrm{Rb}$} & $\mathrm{K}_{\mathrm{d}}[\mathrm{ml} / \mathrm{g}]$ & $9.48 \mathrm{E}+00$ & $0.39774 \mathrm{E}+02$ & $-0.49588 \mathrm{E}+03$ & $0.51485 \mathrm{E}+03$ \\
\hline & $\beta[-]$ & $1.19 \mathrm{E}+00$ & $0.70957 \mathrm{E}+00$ & $-0.78263 \mathrm{E}+01$ & $0.10205 \mathrm{E}+02$ \\
\hline \multirow[t]{2}{*}{$\mathrm{Sr}$} & $\mathrm{K}_{\mathrm{d}}[\mathrm{ml} / \mathrm{g}]$ & $1.31 \mathrm{E}+01$ & $0.81975 \mathrm{E}+02$ & $-0.10284 \mathrm{E}+04$ & $0.10547 \mathrm{E}+04$ \\
\hline & $\beta[-]$ & $1.11 \mathrm{E}+00$ & $0.82831 \mathrm{E}+00$ & $-0.94176 \mathrm{E}+01$ & $0.11631 \mathrm{E}+02$ \\
\hline \multirow[t]{2}{*}{$\mathrm{Zn}$} & $\mathrm{K}_{\mathrm{d}}[\mathrm{ml} / \mathrm{g}]$ & $9.31 \mathrm{E}+00$ & $0.34205 \mathrm{E}+02$ & $-0.42529 \mathrm{E}+03$ & $0.44392 \mathrm{E}+03$ \\
\hline & $\beta[-]$ & $1.20 \mathrm{E}+00$ & $0.66486 \mathrm{E}+00$ & $-0.72471 \mathrm{E}+01$ & $0.96484 \mathrm{E}+01$ \\
\hline
\end{tabular}

the upper soil layer, it would have the potential to contaminate the topsoil, while Mo and other more mobile TEs showed a higher potential to contaminate groundwater.

Unlike most heavy metals, Mo is the most active in alkaline condition ( $\mathrm{pH}>6.5$ ) (Alloway 2013; Hettiarachchi and Gupta 2007), and even, based on previously conducted batch and soil experiments (Wenguang and Selim 2020), at the neutral condition, its mobility is higher than that at the acidic

Table 7 Time of reaching equilibrium conditions (day) for different elements based on the prediction model results (numerical modeling)

\begin{tabular}{ll}
\hline Element & Time of reaching equilibrium conditions (day) \\
\hline $\mathrm{Mo}$ & 100 \\
$\mathrm{Cr}$ & 250 \\
$\mathrm{Rb}$ & 300 \\
$\mathrm{Zn}$ & 500 \\
$\mathrm{Ni}$ & 550 \\
$\mathrm{Ba}$ & 650 \\
$\mathrm{Sr}$ & 700 \\
$\mathrm{~Pb}$ & 800 \\
$\mathrm{As}$ & 1300 \\
$\mathrm{Cu}$ & 1600 \\
\hline
\end{tabular}

condition. The results of the numerical modeling also revealed that due to the fact that the soil of the region is alkaline, this metal is the most active of the 10 simulated metals. In addition, the behavior of Mo in soil is more similar to that of sulfate than other metals (Alloway 2013), and since the amount of both Mo and $\mathrm{SO}_{4}^{2-}$ after passing through the soil is lower than the initial value, it can be concluded that experimental modeling of this metal is also correct.

In the case of $\mathrm{Cr}$, the second most mobile metal, the deduction from former batch experiments has shown that this metal is not easily absorbed by the soil and is highly sensitive to $\mathrm{pH}$ value. At a very acidic $\mathrm{pH}$, chromium adsorption capacity is maximal (Zhang et al. 2018). This proves the result of the carried-out simulation with respect to $\mathrm{Cr}$.

Based on the results of numerical modeling, $\mathrm{Cu}$ and $\mathrm{Pb}$ are among the metals with the least mobility (maximum absorption) in the soil. In confirming this conclusion, it can be explained that $\mathrm{Cu}$ has a lower solubility at high $\mathrm{pH}$; thus copper deposits can form in alkaline soils (Alloway 2013). In addition, at $\mathrm{pH}$ greater than 4.61 , the amount of $\mathrm{Pb}$ absorbed by the soil typically increases, so that in alkaline soils $\mathrm{Pb}$ absorption is high (Fetter et al. 2018). The capacity of clay minerals to adsorb $\mathrm{Pb}$ also increases at higher $\mathrm{pH}$ (Fetter et al. 2018), and due to the fact that these minerals are present in the soil of the research site, it is possible that the local soil increases the 
Fig. 9 Five-year simulation of the impact of treated municipal wastewater on groundwater resources in Nazarabad plain. The simulation of TE concentration in the soil solution at different observation nodes N1, N2, N3, and $\mathrm{N} 4$ represented for the depth of $500 \mathrm{~cm}, 1000 \mathrm{~cm}, 1500 \mathrm{~cm}$, and $2000 \mathrm{~cm}$, respectively, and the different times $\mathrm{T} 1, \mathrm{~T} 2, \mathrm{~T} 3$, and $\mathrm{T} 4$ represented for 456,912 , 1368 , and 1825 days, respectively

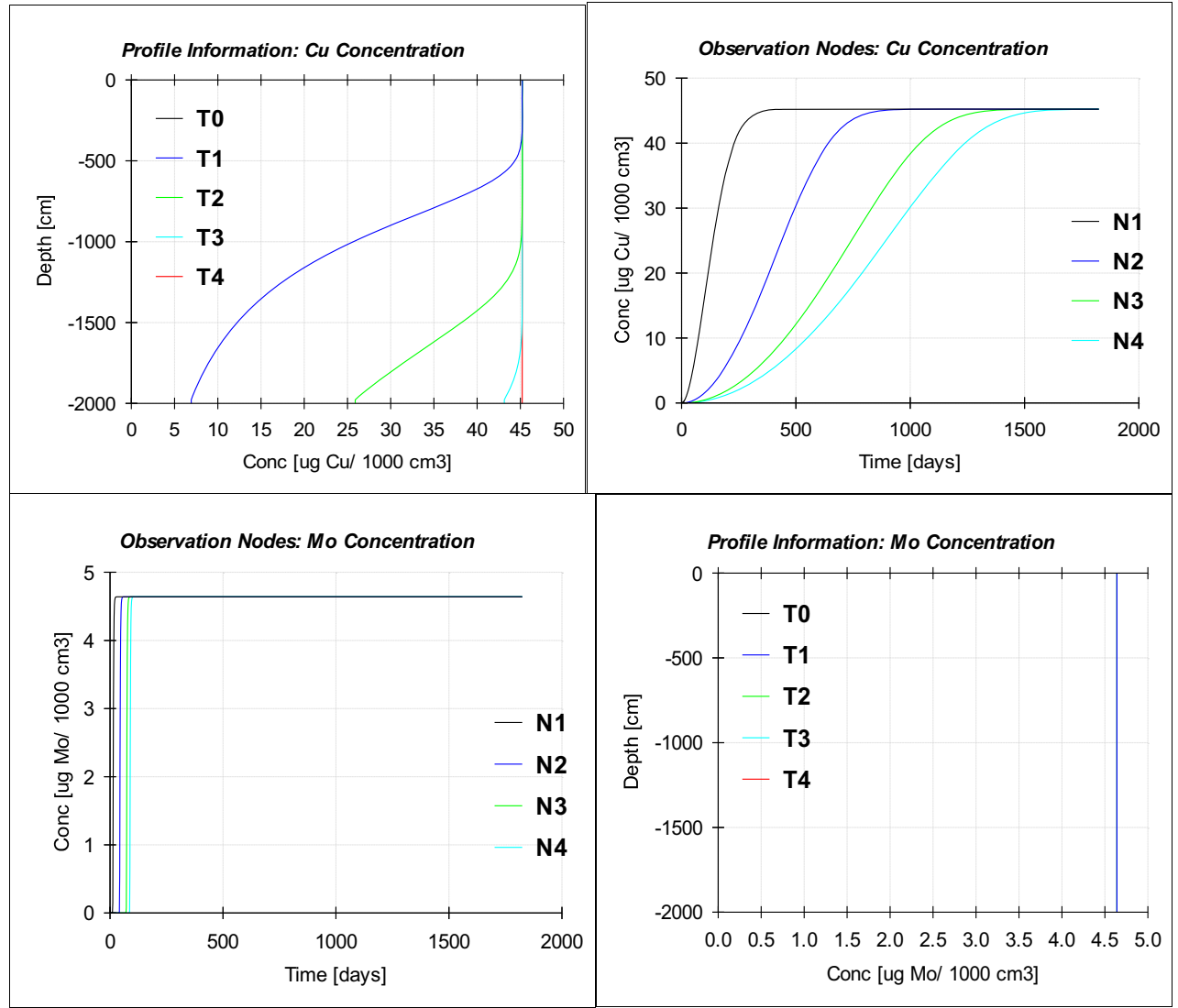

absorption of this metal. Besides, during the adsorption mechanism, arsenic (As) is preserved in soil, so its mobility is limited. As a matter of fact, when the soil $\mathrm{pH}$ is between 4 and 8 , arsenic is least mobile. The presence of adsorbent clay minerals and soil $\mathrm{pH}$ are two important factors in determining the amount of As adsorption (Hassan 2018; Sherameti and Varma 2015).

Furthermore, according to the results of numerical modeling, $\mathrm{Ba}$ and Ni have moderate mobility compared to the other metals and are in the middle range. To justify this, it can be said that the solubility of $\mathrm{Ni}$ is highly dependent on $\mathrm{pH}$, and in alkaline $\mathrm{pH}, \mathrm{Ni}$ is present as hydroxide with limited solubility (Alloway 2013; Chotpantarat et al. 2011). Also, Ba is not very mobile in most soils, and even absorbing this metal from alkaline soils by plants is much more difficult than in acidic soils. In addition, in soils with high amounts of clay minerals and calcium carbonate (calcite), the mobility of barium is limited by surface adsorption and deposition. However, in the presence of chlorine ions, $\mathrm{Ba}$ is more active, and this can prevent the maximum mobility of this element in the soil (Alloway 2013) (experimental modeling has shown an increase in the concentration of chlorine anion compared to the initial value).

Zinc has shown relatively higher mobility (less absorption) than six metals including $\mathrm{Ni}, \mathrm{Ba}, \mathrm{Sr}, \mathrm{Pb}, \mathrm{As}$, and $\mathrm{Cu}$. In justifying this result, it can be said that the adsorption of $\mathrm{Zn}$ decreases in the alkaline environment and most probably in the presence of calcium carbonate (Jennie 1968). In general, the concentration of $\mathrm{Zn}$ per unit of $\mathrm{pH}$ decreases fivefold in the soil (Alloway 2013). Formerly conducted column tests specified that the obtained results from this method appropriately approximate the sorption behavior of zinc during its transport through the soil comparing to batch experiments (Behroozi et al. 2020).

Other simulated elements also showed good adaptation to their natural soil conditions. Regarding strontium ( $\mathrm{Sr}$ ), which its mode of sorption to the soil is $\mathrm{pH}$ dependent, multilayer adsorption occurs above pH 4.5 (Guillén 2018). Rubidium $(\mathrm{Rb})$ is a radioactive element which tends to have a degree of mobility in soil (Schulz 1996). Its uptake in plants is strongly dependent on soil pH (Gjengedal and Steinnes 1994); the higher the soil acidity, the greater the uptake of $\mathrm{Rb}$ by vascular plants and fungi (Tyler 1983).

\section{Conclusions and recommendations}

ICP-MS analysis of primary wastewater showed that all TE concentrations in effluent are within the recommended limits for aquifer recharge. Experimental modeling revealed that, with the exception of As and $\mathrm{Sr}$, there is no regular decreasing or increasing relationship between the concentrations of the 
elements and depth of the soil column. Based on Iranian standards for alkaline soils, the primary soil was not contaminated; however, it was rich in Ba and Sr. Similarly, soil samples did not contain any contaminants after the end of the soil column experiment. In general, except $\mathrm{Ba}, \mathrm{Pb}$, and $\mathrm{Tl}$, the concentration of all TEs in the soil has decreased after the experiment compared to the primary soil. According to the numerical simulation with HYDRUS-1D, copper $(\mathrm{Cu})$, arsenic (As), and lead $(\mathrm{Pb})$ have the most absorption by soil and are slower to become balanced. Molybdenum (Mo) has the highest mobility and is balanced in a shorter time.

The results of physical and numerical modeling show that the soil is somewhat capable of self-purification of heavy metals; while, due to the high hydraulic conductivity, the possibility of contamination of the aquifer with pollutants is high, the infiltration water will not reduce the quality of groundwater because of the low concentration of heavy metals. In fact, as long as the treatment plant works well, it does not pose a risk of groundwater pollution. Therefore, continuous monitoring of the characteristics of the treated effluent of the treatment plant is vital.

Due to the use of treated wastewater of Nazarabad municipal treatment plant in irrigation of farms and agricultural activities, it is recommended to monitor other unknown characteristics of wastewater, such as microbiological parameters, to finally ensure the consumption of effluent in this sector. It should be mentioned that previous reports provided by the refinery itself have indicated the presence of two different classes of helminths (Taenia saginata and Ascaris lumbricoides) in the treated wastewater. Besides, it is indispensable for the treatment plant officials to take the necessary measures to reduce the nitrate pollution in the effluent.

Acknowledgements We would like to thank Mr. Hamidreza Samani, the director of Nazarabad water and sewerage department, for his cooperation in the early stages of this research, including soil and wastewater sampling.

Author contribution Both authors contributed to the study conception and design. Material preparation, data collection, and analysis were performed by Nezhla Amiri and Mohammad Nakhaei. The first draft of the manuscript was written by both authors, and they commented on previous versions of the manuscript. Both authors read and approved the final manuscript.

Data availability All data are provided in the manuscript.

\section{Declarations}

Ethics approval Not applicable.

Consent to participate All authors made substantial contributions to the conception, design, use of software, data interpretation, and all the steps involved in this work.
Consent for publication Both authors have approved the version to be published.

Competing interests The authors declare no competing interests.

Open Access This article is licensed under a Creative Commons Attribution 4.0 International License, which permits use, sharing, adaptation, distribution and reproduction in any medium or format, as long as you give appropriate credit to the original author(s) and the source, provide a link to the Creative Commons licence, and indicate if changes were made. The images or other third party material in this article are included in the article's Creative Commons licence, unless indicated otherwise in a credit line to the material. If material is not included in the article's Creative Commons licence and your intended use is not permitted by statutory regulation or exceeds the permitted use, you will need to obtain permission directly from the copyright holder. To view a copy of this licence, visit http://creativecommons.org/licenses/by/4.0/.

\section{References}

Abel C (2014) Soil aquifer treatment: assessment and applicability of primary effluent reuse in developing countries, Taylor \& Francis. https://doi.org/10.1007/s12665-017-6692-8

Ahuja S (ed) (2008) Arsenic contamination of groundwater: mechanism, analysis, and remediation, 1st edn. John Wiley \& Sons, Inc. https:// doi.org/10.1002/9780470371046

Alloway B (2013) In: Alloway B, Trevors J (eds) Heavy metals in soils: trace metals and metalloids in soils, Vol. 22, third eds. Springer science+business media, Dordrecht. https://doi.org/10.1007/978 94-007-4470-7

Alslaibi T, Kishawi Y, Abunada Z (2017) Evaluating impacts of recharging partially treated wastewater on groundwater aquifer in semi-arid region by integration of monitoring program and GIS technique. Environ Sci Pollut Res 24(15):13674-13686. https:// doi.org/10.1007/s11356-017-8789-8

ASTM-International. (2014). Guide lining protocol for soil-column experiments assessing fate and transport of trace organics, Sieve Analysis (ASTM D6913). (American Society for Testing and Materials) Retrieved from http://www.astm.org

Aydin M, Aydin S, Beduk F, Tor A, Tekinay A, Kolb M, Bahadir M (2015) Effects of long-term irrigation with untreated municipal wastewater on soil properties and crop quality. Environ Sci Pollut Res 22(23):19203-19212. https://doi.org/10.1007/s11356-0155123-1

Bégin L, Fortin J, Caron J (2003) Evaluation of the fluoride retardation factor in unsaturated and undisturbed soil columns. Soil Sci Soc Am J 67:1635-1646. https://doi.org/10.2136/sssaj2003.1635

Behroozi A, Arora M, Fletcher T, Western A (2020) Sorption and transport behavior of zinc in the soil; Implications for stormwater management. Geoderma 367:114243. https://doi.org/10.1016/j. geoderma.2020.114243

Belhaj D, Jerbi B, Medhioub M, Zhou J, Kallel M, Ayadi H (2015) Impact of treated urban wastewater for reuse in agriculture on crop response and soil ecotoxicity. Environ Sci Pollut Res 23(16):1587715887. https://doi.org/10.1007/s11356-015-5672-3

Berkowitz B, Dror I, Yaron B (2014) Contaminant geochemistry: interactions and transport in the subsurface, 2nd edn. Springer-Verlag, Berlin Heidelberg. https://doi.org/10.1007/978-3-642-54777-5 
Bromly M, Hinz C, Aylmore L (2007) Relation of dispersivity to properties of homogeneous saturated repacked soil columns. Eur J Soil Sci 58:293-301. https://doi.org/10.1111/j.1365-2389.2006.00839.x

Carrillo-González R, Šimůnek J, Sauve', S., \& Domy, A. (2006) Mechanisms and pathways of trace element mobility in soils. Adv Agron 91:111-178. https://doi.org/10.1016/S0065-2113(06)910037

Charkhestani A, Saleh Ziri M, Amini Rad H (2015) Wastewater reuse: potential for expanding Iran's water supply to survive from absolute scarcity in future. Journal of Water Reuse and Desalination 6(4):8 444. https://doi.org/10.2166/wrd.2015.210

Chotpantarat S, Ong S, Sutthirat C, Khemarath O (2011) Effect of pH on transport of $\mathrm{Pb} 2+, \mathrm{Mn} 2+, \mathrm{Zn} 2+$ and $\mathrm{Ni2}+$ through lateritic soil: column experiments and transport modeling. J Environ Sci-China 23(4):640-648. https://doi.org/10.1016/S1001-0742(10)60417-2

Chu A, Khương M, Phạm V, Nguyễn N, Nguyễn M (2014) Application of Hydrus -1D model to simulate the transport of some selected heavy metals in Paddy soil in Thanh Trì, Hanoi. VNU J Sci: Earth Environ Sci 30(1):22-30 Retrieved from https://js.vnu.edu.vn/ EES/article/view/754

Communar G, Keren R, Li F (2004) Deriving boron adsorption isotherms from soil column displacement experiments. Soil Sci Soc Am 68: 481-488. https://doi.org/10.2136/sssaj2004.4810

Corwin D (2000) Evaluation of a simple lysimeter-design modification to minimize sidewall flow. J Contam Hydrol 42:35-49

Das BM (1985) Introduction to geotechnical engineering, 7th edn. Cengage Learning, Boston

Delleur JW (1999) Elementary groundwater flow and transport processes. In: The Handbook of Groundwater Engineering (ed) pp. 10-11, 2nd eds. Taylor \& Francis, CRC Press

Douglas W, McConchie D (1994) Analytical Sedimentology, Springer US. https://doi.org/10.1007/978-1-4615-2636-0

Drinan J, Spellman F (2013) Water and wastewater treatment: a guide for the nonengineering professional, 2nd eds. Taylor \& Francis

Eslamian S, Eslamian FA (2017) Handbook of drought and water scarcity: environmental impacts and analysis of drought and water scarcity, Vol. 1, 1st eds. Taylor \& Francis, CRC press

FAO (2003) Users manual for irrigation with treated wastewater. FAO Regional Office for the Near East, Cairo, Egypt Retrieved from http://www.fao.org

Fares A, Singh SK (2020) Arsenic water resources contamination: challenges and solutions, 1st eds. Springer International Publishing. https://doi.org/10.1007/978-3-030-21258-2

Fatta-Kassinos D, Dionysiou D D and Kummerer K, (2016). The handbook of environmental chemistry (series title): Advanced treatment technologies for urban wastewater reuse (1 ed., Vol. 45), Springer International Publishing, Switzerland. https://doi.org/10.1007/9783-319-23886-9

Fetter C, Boving TB, Kreamer DK (2018) Chapter 6: inorganic chemicals in groundwater. In Contaminant Hydrogeology (Third Edition ed., pp. 347-358). Waveland Press, Inc. https://doi.org/10.1007/ s12665-018-7921-5

Gjengedal E, Steinnes E (1994) The mobility of metals in the soil-plant system in manipulated catchments: plant species suitable for biomonitoring of $\mathrm{cd}, \mathrm{Pb}, \mathrm{Zn}$, and $\mathrm{Rb}$. Ecol Eng 3:267-278. https:// doi.org/10.1016/0925-8574(94)90055-8

Glass R, Steenhuis T, Yves PJ (1989) Mechanism for finger persistence in homogeneous, unsaturated, porous media: theory and verification. Soil Sci 148(1):60-70

Gotkowitz M, Bradbury K, Borchardt A, Zhu J, Spencer K (2016) Effects of climate and sewer condition on virus transport to groundwater.
Environ Sci Technol. 50(16):8497-8504. https://doi.org/10.1021/ acs.est.6b01422

Guillén J (2018) Factors influencing the soil to plant transfer of strontium. In: Dharmendra K, Clemens W (eds) Behaviour of strontium in plants and the environment, 1st edn. springer. https://doi.org/10. 1007/978-3-319-66574-0

Hassan MM (2018) Arsenic in Groundwater: Poisoning and Risk Assessment (1st ed.). CRC Press. https://doi.org/10.1201/ 9781315117034

Hettiarachchi GM, Gupta UC (2007) Boron, molybdenum, and selenium. In: Webster R, Carter M, Gregorich E (eds) Soil sampling and methods of analysis, 2nd edn. CRC Press, Boca Raton. https://doi. org/10.1201/9781420005271

Hussain M, Qureshi A (2020) Health risks of heavy metal exposure and microbial contamination through consumption of vegetables irrigated with treated wastewater at Dubai, UAE. Environ Sci Pollut Res 27(10):11213-11226. https://doi.org/10.1007/s11356-019-07522-8

Iranian Department of Environment (2019) Department of Environment: Standards and Indicators (in Persian). Retrieved from http://www. doe.ir

Jafari M, Tavili A, Panahi F, Zandi Esfahan E, Ghorbani M (2018) Reclamation of arid lands. In: Management of Water Resources, 1st eds. Springer International Publishing, pp 93-165. https://doi. org/10.1007/978-3-319-54828-9

Jennie $\mathrm{E}$ (1968) Controls on $\mathrm{Mn}, \mathrm{Fe}, \mathrm{Co}, \mathrm{Ni}, \mathrm{Cu}$, and $\mathrm{Zn}$ concentrations in soils and water: the significant role of hydrous $\mathrm{Mn}$ and Fe oxides. In: Gould R (ed) Trace Inorganics In Water (Vol. 73, pp. 337-387). American Chemical Society. https://doi.org/10.1021/ba-1968-0073. ch021

Keesstra S, Geissen V, Mosse K, Pirranen S, Scudiero E, Leistra M, Schaik L (2012) Soil as a filter for groundwater quality. Curr Opin Environ Sustain 4(5):507-516. https://doi.org/10.1016/j.cosust. 2012.10.007

Keremane G (2017) Governance of urban wastewater reuse for agriculture: a framework for understanding and action in metropolitan regions, 1st edn. Springer International Publishing, Adelaide. https:// doi.org/10.1007/978-3-319-55056-5

Kirkham D, Powers WL (1972) Advanced soil physics. WileyInterscience, New York.

Lewis J, Sjöstrom J (2010) Optimizing the experimental design of soil columns in saturated and unsaturated transport experiments. J Contam Hydrol 115:1-13. https://doi.org/10.1016/j.jconhyd.2010. 04.001

Mahmoudi N, Nakhaei M, Porhemmat J (2018) Assessment of an arid region soil capacity on natural attenuation of municipal treated wastewater a column experiment using soil of Varamin area, Iran. Environ Earth Sci 77:140. https://doi.org/10.1007/s12665-0187292-y

Maliva R, Missimer T (2012) Arid lands water evaluation and management. Springer-Verlag Berlin Heidelberg. https://doi.org/10.1007/ 978-3-642-29104-3

Mamindy-Pajany Y, Sayen S, Guillon E (2013) Impact of sewage sludge spreading on nickel mobility in a calcareous soil: adsorptiondesorption through column experiments. Environ Sci Pollut Res 20(7):4414-4423. https://doi.org/10.1007/s11356-012-1357-3

Martins T, Leitao T, Carvalho M (2017) Assessment of wastewater contaminants retention for a soil-aquifer treatment system using soilcolumn experiments. Proc Earth Planet Sci 17:332-335. https://doi. org/10.1016/j.proeps.2016.12.084

McBride M (1995) Toxic metal accumulation from agricultural use of sludge: are USEPA regulations protective? J Environ Qual 24:5-18. https://doi.org/10.2134/jeq1995.00472425002400010002x 
Missimer T, Drewes J, Amy G, Maliva R, Keller S (2012) Restoration of Wadi aquifers by artificial recharge with treated waste water. Ground Water 50(4):514-527. https://doi.org/10.1111/j.17456584.2012.00941.x

Mojid M, Hossain A, Wyseure G (2019) Impacts of municipal wastewater on basic soil properties as evaluated by soil column leaching experiment in laboratory. J Soil Sci Plant Nutr 19(2):402-412. https://doi.org/10.1007/s42729-019-00042-x

Naka A, Yasutaka T, Sakanakura H, Kalbe U, Watanabe Y, Inoba S et al (2016) Column percolation test for contaminated soils- key factors for standardization. J Hazard Mater 320:326-340. https://doi.org/10. 1016/j.jhazmat.2016.08.046

National Research Council (1984) Groundwater contamination. The National Academies Press, Washington. https://doi.org/10.17226/ 1770

Novák V, Hlaváčiková H (2019) Applied soil hydrology, theory and application of transport in porous media, Vol. 32, 1st edn. Springer international publishing. https://doi.org/10.1007/978-3030-01806-1

Oliviera I, Demond A, Salehzadeh A (1996) Packing of sands for the production of homogeneous porous media. Soil Sci Soc Am 60: $49-53$

Pescod, M (1992) Wastewater treatment and use in agriculture. Food and Agriculture Organization of the United Nations

Phogat V, Mallants D, Cox J, Šimůnek J, Oliver D, Pitt T, Petrie P (2020) Impact of long-term recycled water irrigation on crop yield and soil chemical properties. Agric Water Manag 237:237. https://doi.org/ 10.1016/j.agwat.2020.106167

Plekhanova I (2017) Self-purification of agrosoddy-podzolic sandy loamy soils fertilized with sewage sludge. Eurasian Soil Sci 50(4): 491-497. https://doi.org/10.1134/S1064229317040081

Radcliffe D, Šimůnek J (2010) Soil physics with HYDRUS: modeling and applications. Taylor \& Francis, CRC Press. https://doi.org/10. 1201/9781315275666

Schulz R (1996) Soil chemistry of radionuclides. Health Phys 11:13171324. https://doi.org/10.1097/00004032-196512000-00008

Selim H (2013) Competitive sorption and transport of heavy metals in soils and geological media. Taylor \& Francis, CRC Press

Selker J, McCord J, Keller C (1999) Vadose zone processes. Taylor \& Francis, CRC Press.

Sentenac P, Lynch R, Bolton M (2001) Measurement of a side-wall boundary effect in soil columns using fibre-optics sensing. Int $\mathrm{J}$ Phys Modell Geotech 1:35-41. https://doi.org/10.1680/ijpmg. 2001.010404

Sherameti I, Varma A (2015) Heavy metal contamination of soils: monitoring and remediation, vol Vol. 44. Springer international publishing, Switzerland. https://doi.org/10.1007/978-3-319-14526-6
Siebe C, Chapela-Lara M, Cayetano-Salazar M, Prado B, Siemens J (2018) Effects of more than 100 years of irrigation with Mexico City's wastewater in the Mezquital Valley (Mexico). In: Hettiarachchi H, Ardakanian R (eds) Safe use of wastewater in agriculture: good practice examples. Springer, Cham, pp 121-138. https://doi.org/10.1007/978-3-319-74268-7

Šimůnek J, van Genuchten M (2008) Modeling nonequilibrium flow and transport processes using HYDRUS. Vadose Zone J 7(2):782-797. https://doi.org/10.2136/vzj2007.0074

Šimůnek J, van Genuchten M, Šejna M (2012) Hydrus: model use, calibration, and validation. Trans ASABE 55(4):1261-1274

Šimůnek J, Šejna M, Saito H, Sakai M, van Genuchten M (2013) The Hydrus-1D software package for simulating the movement of water, heat, and multiple solutes in variably saturated media, Version 4.17, HYDRUS Software Series 3. Department of Environmental Sciences, University of California Riverside, Riverside

Šimůnek J, van Genuchten M, Šejna M (2016) Recent developments and applications of the HYDRUS computer software packages. Vadose Zone J 15(7):1-25. https://doi.org/10.2136/vzj2016.04.0033

Su C, Jiang L, Zhang W (2014) A review on heavy metal contamination in the soil worldwide: situation, impact and remediation techniques. Environ Skept Crit:24-38

Todd DK, Mays LW (2005) Groundwater hydrology, 3rd edn. John Wiley \& Sons, Inc

Tyler G (1983) Rubidium - availability and plant uptake in natural soils. Commun Soil Sci Plant Anal 14(11):1075-1089. https://doi.org/10. 1080/00103628309367433

Vodyanitskii Y (2013) Contamination of soils with heavy metals and metalloids and its ecological hazard (analytic review). Eurasian Soil Sci 46(7):793-801. https://doi.org/10.1134/ S1064229313050153

Weihermüller L, Siemens J, Deurer M, Knoblauch S, Rupp H, Göttlein H, Pütz T (2007) In situ soil water extraction: a review. J Environ Qual 36:1735-1748

Wenguang S, Selim H (2020) Kinetic modeling of molybdenum sorption and transport in soils. Environ Sci Pollut Res 27:20227-20234. https://doi.org/10.1007/s11356-020-08546-1

WHO (2006) A compendium of standards for wastewater reuse in the eastern Mediterranean region. World Health Org, Retrieved from http://www.who.int

Zhang X, Tong J, Hu B, Wei W (2018) Adsorption and desorption for dynamics transport of hexavalent chromium $(\mathrm{Cr}(\mathrm{VI}))$ in soil column. Environ Sci Pollut Res 25(1):459-468. https://doi.org/10.1007/ s11356-017-0263-0

Publisher's note Springer Nature remains neutral with regard to jurisdictional claims in published maps and institutional affiliations. 